\title{
MOISTURE CONTENT OF PEACH BUDS IN RELATION TO TEMPERATURE EVALUATIONS
}

\author{
EARI S. JOHNTON \\ (WITH TWO FIGURES)
}

The moisture content of peach fruit buds shows a marked increase in late winter and early spring. Experiments performed at the Maryland Agricultural Experiment Station in I9I9 show that moisture values based on the dry weight of buds increased from an average ratio of 0.69 on January 7 to 3.65 on March 28 . The following year the average ratio increased from 0.73 on January 29 to $3.5 \mathrm{I}$ on April I. Such marked increases come after the end of the rest period. CHANDLER ${ }^{\mathrm{I}}$ has shown for several varieties of peach that the rest period ends during the latter part of December or the first part of January. The work of AUCHTER in I9I9 (unpublished), at the Maryland Experiment Station, shows that the rest period for fruit buds of six peach varieties was completed by December 25. It is true that there is a fluctuation in the moisture content of dormant buds, but such variations are slight in comparison with those coming at the time the buds start their growth. Concerning buds of the plum, STRAUSBaUgh ${ }^{2}$ states:

During the period of dormancy the moisture content of the semihardy varieties fluctuates with the temperature. Periods of low temperatures are accompanied by a loss of moisture from the leaf and fruit buds, and higher winter temperatures, which are seldom above freezing in Minnesota, by an increase in moisture content.

It is interesting to note that the moisture content of his hardy variety, Assiniboine, remained fairly constant during dormancy.

Since the increase in moisture content following dormancy seems to be related to growth of the bud, an examination has been made of the available moisture data of peach fruit buds and of

I Chandler, W. H., Winter killing of peach buds as influenced by previous treatment. Mo. Agric. Exp. Sta. Bull. 74. I907.

${ }^{2}$ Strausbaugh, P. D., Dormancy and hardiness in the plum. Bot. Gaz. 6r: 337-357. I92I.

Botanical Gazette, vol. 74] 
temperature data obtained during the last three years (I9I9-I92I) at the Maryland Station. The I9r9 data include those previously reported by Johnston. ${ }^{3}$ Fifteen Elberta and fifteen Greensboro trees are averaged for this year's data. The 1920 data have not yet been reported, but are the averages of twenty-seven trees, representing eighteen varieties. The buds of this year were collected from an orchard that had been severely pruned the year previous. The I92I data are very meager, having been obtained from two trees only, one an Elberta, the other a Greensboro. Moisture determinations, however, were made more frequently during this year.

\section{Temperature evaluations}

Three kinds of temperature indices have been applied to these moisture data. In making use of the remainder indices, it is

TABLE I

MOISTURE CONTENT OF PEACH BUDS WITH CORRESPONDING TEMPERATURE INDICES SUMMED FROM JANUARY I OF EACH YEAR

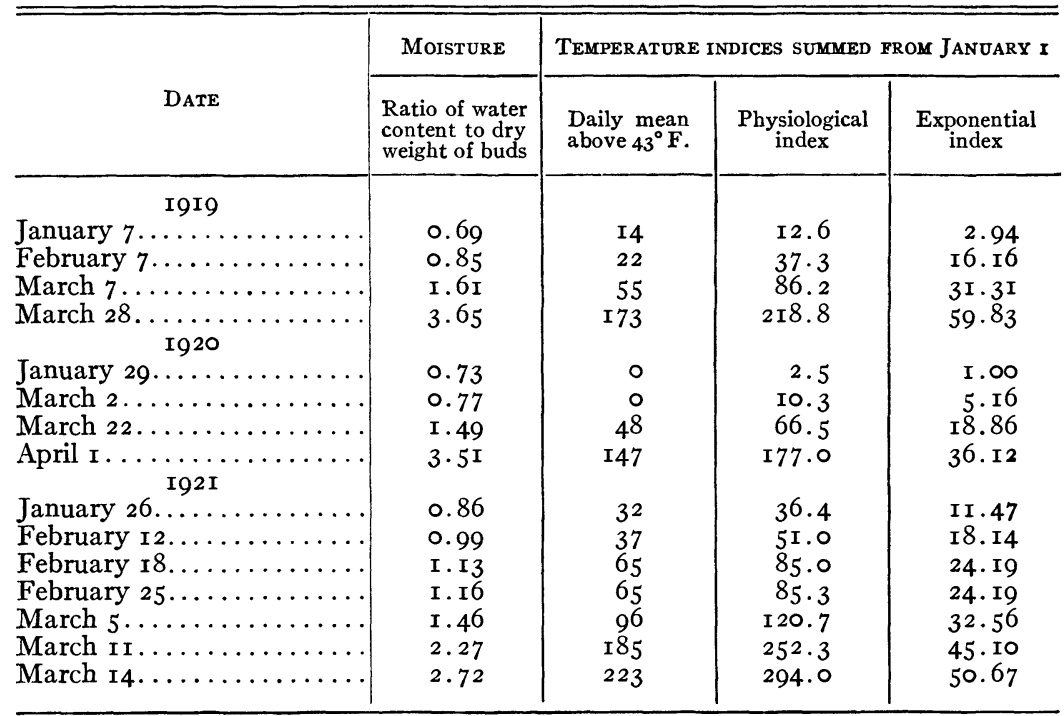

assumed that $43^{\circ} \mathrm{F} .\left(6 . \mathrm{I}^{\circ} \mathrm{C}\right.$.) is the "zero" for growth and other physiological processes, and that daily mean temperatures above

3 Johnston, Earl S., An index of hardiness in peach buds. Amer. Jour. Bot. 6:273-379. I9I9. 
$43^{\circ}$ are "effective" units. These daily mean temperatures (average of daily maximum and minimum) above $43^{\circ}$ have been summed from January I to each date on which the moisture determinations were made. The physiological summation indices, as derived by Livingston, ${ }^{4}$ were obtained from the daily mean temperatures,

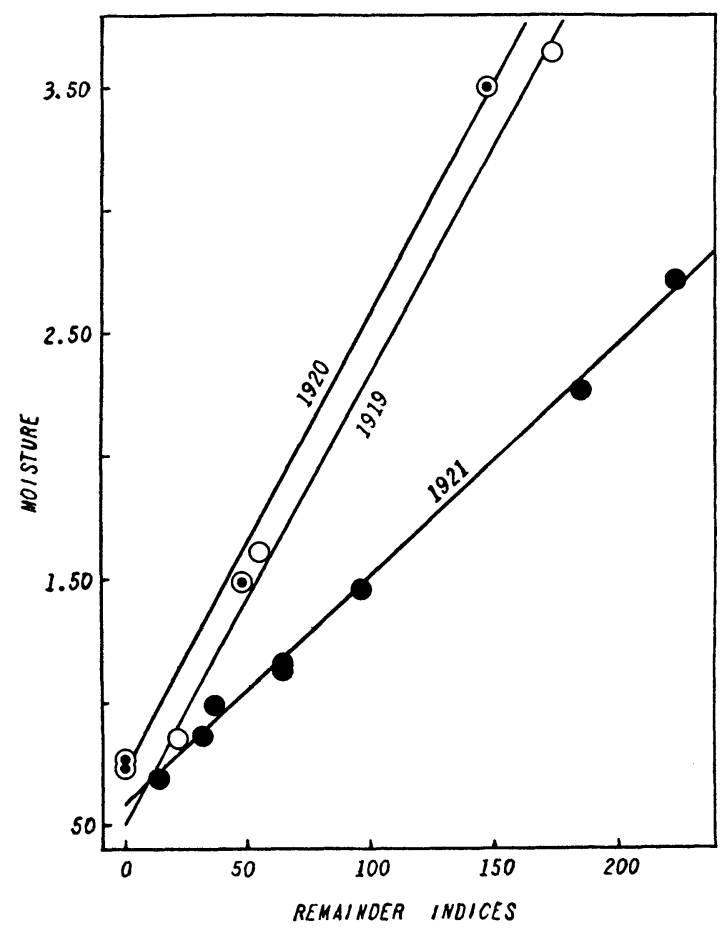

FIG. I.-Moisture content of peach buds plotted against remainder indices summed from January $I$ for years I9I9-I92I.

and are likewise summed from January I to each particular date. The chemical efficiency indices proposed by Lrvingston and LIVINGSTON $^{5}$ were summed from the indices corresponding to the daily mean temperatures. These three kinds of temperature indices are presented, together with the moisture data, in table I.

4 Livingston, B. E., Physiological temperature indices for the study of plant growth in relation to climatic conditions. Physiol. Res. I:399-420. I916.

5 Livingston, B. E., and Lrvingston, G. J., Temperature coefficients in plant geography and climatology. Вот. Gaz. 56:349-375. I9r3. 
A general survey of the temperature indices in table $I$ at once shows that the I920 season was colder and less advanced by April I than those of I9I9 and I92I on March 28 and March II, respectively. If the sum of the daily mean temperatures above $43^{\circ}$ be used as the criterion, it is seen that the season of I92I was more advanced on February 18 than the I9I9 season on March 7 , and the season of 1920 on March 22. The moisture content of the fruit

\section{TABLE II}

MOISTURE CONTENT OF PEACH BUDS WITH CORRESPONDING TEMPERATURE INDICES SUMMED FROM JANUARY I OF EACH YEAR, EXPRESSED AS NUMBERS RELATIVE TO EACH SEASONAL RANGE, FIRST AND LAST VALUES BEING O AND I.OO RESPECTIVELY

\begin{tabular}{|c|c|c|c|c|}
\hline \multirow[b]{2}{*}{ Date } & \multirow{2}{*}{$\begin{array}{l}\text { MOISTURE } \\
\text { Ratio of water } \\
\text { content to dry } \\
\text { weight of buds }\end{array}$} & \multicolumn{3}{|c|}{ TEMPERATURE INDICES SUMMED FROM JANUARY I } \\
\hline & & $\begin{array}{l}\text { Daily mean } \\
\text { above } 43^{\circ} \mathrm{F} .\end{array}$ & $\begin{array}{l}\text { Physiological } \\
\text { index }\end{array}$ & $\begin{array}{l}\text { Exponential } \\
\text { index }\end{array}$ \\
\hline r9r9 & & & & \\
\hline January $7 \ldots \ldots \ldots \ldots$ & o & 0 & 0 & 0 \\
\hline February $7 \ldots \ldots \ldots \ldots \ldots$ & 0.05 & 0.05 & 0.12 & 0.23 \\
\hline $\operatorname{March} 7 \ldots \ldots \ldots \ldots$ & $0.3^{I}$ & 0.26 & 0.36 & 0.50 \\
\hline March $28 \ldots \ldots \ldots \ldots \ldots \ldots$ & I. .0 & I. .0 & I. .0 & I. 00 \\
\hline January $29 \ldots \ldots \ldots \ldots \ldots$ & ○ & ○ & ○ & ○ \\
\hline March $2 \ldots \ldots \ldots \ldots \ldots$ & 0.01 & o & 0.04 & O. I 2 \\
\hline March $22 \ldots \ldots \ldots \ldots \ldots$ & 0.27 & 0.33 & 0.37 & $0.5 \mathrm{I}$ \\
\hline April $1 \ldots \ldots \ldots \ldots \ldots \ldots$ & I. .0 & I. . O & I. .0 & I. .00 \\
\hline January $26 \ldots \ldots \ldots \ldots$ & ○ & o & o & ○ \\
\hline February r $2 \ldots \ldots \ldots$ & 0.07 & 0.03 & 0.06 & 0.17 \\
\hline February $18 \ldots \ldots \ldots$ & 0.15 & 0.17 & o. I9 & 0.32 \\
\hline February $25 \ldots \ldots \ldots$ & 0.16 & o. 17 & 0.19 & 0.32 \\
\hline March $5 \ldots \ldots \ldots \ldots$ & 0.32 & 0.34 & 0.33 & 0.54 \\
\hline 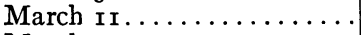 & 0.76 & 0.80 & 0.84 & 0.86 \\
\hline March $14 \ldots \ldots \ldots \ldots$ & $\mathrm{r} .00$ & I. .0 & $1 . \infty 0$ & 1.00 \\
\hline
\end{tabular}

buds on January 26 , I92I, was practically the same as that on February 7, 1919, and somewhat greater than that on March 2, I920. Such early development of buds increases the danger of fruit loss by spring freezes.

The moisture values given in table I have been plotted against the summation values of the daily mean temperatures above $43^{\circ} \mathrm{F}$., and are presented in fig. I. The slopes of the I9I9 and I920 curves are practically the same, while that of I92I is quite different. There are apparently some conditioning influences at work before January I that determine the slopes of these curves. 
After the slopes have once been "predetermined," the increase seems to depend mainly on temperature, either directly or indirectly. It is thus possible to predict the moisture content of the buds for any date after the first of January to the time the pink petals of

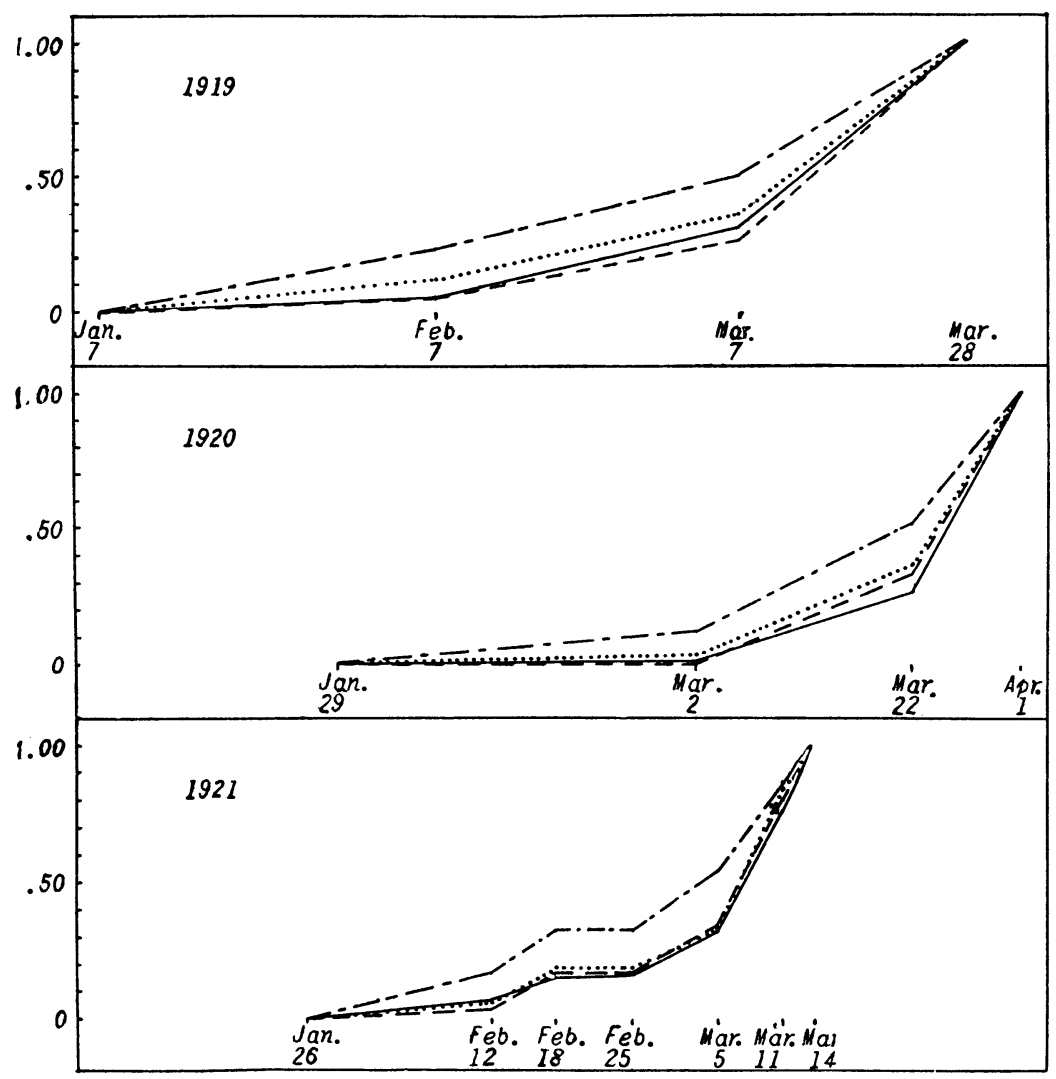

FIG. 2.-Proportionate increase in moisture content of peach buds (continuous lines) and corresponding increases in remainder indices (dash lines), physiological indices (dot lines), and exponential indices (dash-dot lines) for years rgr9-rg2r.

the buds begin to show. The daily mean temperatures and the origin of the slope of the curve must be known. If the origin be considered the first moisture value with its corresponding temperature summation after January $\mathrm{I}$, or after the end of the rest period, then the slope can be determined from one other later moisture determination. 
The other temperature data in table I were also plotted against the corresponding moisture values, but are not presented in graphic form. The curves obtained by using the physiological indices were practically straight lines, and quite similar to those obtained from the daily mean temperatures above $43^{\circ} \mathrm{F}$. The relationship between the moisture and the exponential indices, however, was not linear.

The data of table I have been rearranged so that the first reading of each measurement for each year is zero and the last unity. Within this range it is somewhat easier to compare the proportionate amount of change in each measurement. These data are presented in table II, and in the form of graphs in fig. 2. The close agreement between the moisture and the temperature indices representing the summation of daily mean temperatures above $43^{\circ} \mathrm{F}$. is readily seen.

\section{Conclusions}

It is realized that the observations discussed in this paper are somewhat limited in number, but nevertheless they suggest a definite relationship between air temperature and the rate of increase in the moisture content of peach fruit buds. There can be little doubt, however, that other conditioning influences are operative before January $\mathrm{I}$, that determine the manner in which these buds responded to temperature.

Agricultural Experiment Station

UNIVERSITY OF MARYLAND

College Park, MD. 